\title{
ORGANIZATIONAL AND CORPORATE IDENTITY REVISITED: TOWARDS A \\ COMPREHENSIVE UNDERSTANDING OF IDENTITY IN BUSINESS
}

\begin{abstract}
Purpose - This paper provides a comprehensive and integrative review of academic literature analyzing identity in business. The literature review proposed by the authors helps clearing up theoretical and practical understanding of this concept.
\end{abstract}

Design/methodology/approach - A review of existing literature in organizational behavior and marketing fields is proposed to clarify the meaning of organizational and corporate identity. Based on this review, the authors also identify an integrative perspective proposed for managers to identify and effectively manage all dimensions of their business identities.

Findings - Literature on the identity of businesses is extensive and blurred, failing to provide useful guidance for practitioners to manage this concept. A new approach proposes understanding this kind of identity as a global concept that integrates proposals from diverse research fields in order to take advantage of cross-fertilization.

Practical implications - This research allows identity and communication managers to understand dimensions of business identity for a more effective management of this concept in their organizations.

Originality/value - The line of research that proposes an integrative multidisciplinary approach to the study of identity in business is quite new and, as so, it still needs further contributions to clarify this nascent domain. In this paper, the authors also classify previous studies on business identity according to the theoretical approach they assume (Table 3) just as no other research has done before.

Keywords - Corporate identity; organizational identity; corporate personality; corporate communication; corporate identity mix; corporate identity management mix.

Paper type - Literature review 


\section{Introduction}

The marketing discipline is currently facing a new paradigm shift oriented towards the theoretical approach proposed by corporate marketing. The notion of corporate marketing was first introduced by Balmer (1998), who years later refined his proposal in several subsequent papers (e.g., Balmer, 2001a, 2009, 2011; Balmer and Greyser, 2003, 2006; He and Balmer, 2005, 2007; Balmer et al., 2011 or Illia and Balmer, 2012). An extent discussion on the origins and ideas of this perspective appears in Balmer and Greyser (2003). For the purpose of our review, we can summarize the essential idea brought to literature by corporate marketing as one that gives a special significance to the institutional level of organizations, which practitioners should manage carefully in current competitive markets. It is believed that organizational and brand attributes are more durable and resistant to competitive pressures than products and services attributes. Consequently, nowadays it is not unusual to see companies especially caring for their own characteristics at corporate level and researchers have also developed extensive research on concepts closely linked to the company as a whole (e.g., corporate identity, image, reputation, communication or branding, among others).

The corporate marketing approach reviews the variables in the marketing mix and defines 6 C's, representing the fundamental concepts to understand this new marketing discipline: character (referred to corporate identity), culture (organizational identity), covenant (corporate branding), conceptualizations (reputation or corporate image), communications (corporate communication) and constituencies (management of stakeholders). Nevertheless, the close connection between all these concepts makes it difficult to examine and define each without resorting to the others (Balmer and Greyser, 2006). This fact leads to the appearance of numerous approaches to the study of corporate marketing in academic literature, which fail to 
provide a shared and global definition and, in so doing, complicate the understanding of corporate marketing (Christensen and Askegaard 2001; Souiden et al., 2006; Walker, 2010).

This is especially the case of one of the most outstanding concepts in corporate marketing: identity. Business identity was defined by Balmer (2001a) as "an umbrella label used to cover corporate personality, organizational identification and visual identity”. This identity serves as a basis to explain the vast majority of corporate marketing concepts such as image or reputation, among others (Balmer and Greyser, 2003). For example, even though a company does not have enough power to directly determine its public image, it may influence its formation through proper management of its business identity (Dutton and Dukerich, 1991; Dowling, 1994; van Riel, 1995; Hooghiemstra, 2000; Karaosmanoglu and Melewar, 2006). In this regard, Karaosmanoglu and Melewar (2006) consider that corporate image is formed from the projection of all signs that make up the identity of the company, so that both concepts are closely linked (Hatch and Schultz, 1997; Christensen and Askegaard, 2001). Consequently, business identity has become an increasingly important concept in business (Melewar and Karaosmanoglu, 2006) and its management is a key element of corporate strategy (Melewar et al., 2006).

Nevertheless, "the fog which has enveloped the nascent domain of corporate marketing" (Balmer, 2001a) leads to the concept provided in the previous paragraph being a controversial definition of business identity (Melewar and Wooldridge, 2001). When explaining this notion, there has been some confusion in literature, authors tending to define it in an intertwined way with other related concepts. In most occasions these problems derive from the diversity of scholars who have analyzed this business reality from different fields such as organizational behavior, marketing, strategy, psychology or corporate communications (Balmer and 
Wilkinson, 1991; van Rekom et al., 2008). Based on these ideas, Balmer and Wilkinson (1991), for example, identify as many as eight conceptualizations for identity in business, labeled as Corporate Identity, Corporate Image, Corporate Personality, Corporate Culture, House Style, Corporate Philosophy, Visual Image and Generic Image, this last one referring to the influence of the industry image on corporate identity.

Quite frequently we can also find approaches which mix corporate and organizational identity, two different but related orientations to the study of this domain. On the one hand, corporate identity refers to a marketing approach to identity in businesses. This stream of research tends to see identity as (1) a tangible institutional reality; (2) which has an overt external, customer/stakeholder orientation and (3) which accords special attention to practical and managerial perspectives. "References to the concept (corporate identity) dates at least as far back as 1964" (Balmer, 2008). On the other hand, among organizational behaviorists the concept of organizational identity enjoys a hegemonic status in their common parlance. This dimension of business identity (1) is relatively newer than that of corporate identity; (2) has an internal/employee foci and (3) it is grounded in perceptions of the organization by corporate members.

Although organizational and corporate identities are the most salient streams of research analyzing identity in business (Balmer, 2008), their respective foci tends to be different and, as so, clearly defining which concept is being referred is essential for the message of researchers to get through. Nonetheless, this is something that has not been very common in academic literature, a fact that has led to misunderstandings and the proposal of extensive overviews and models which complicate the identification of the differences and connections between corporate and organizational identities. Cornelissen et al. (2007) highlight that 
"while points of contact exist, many have not been fully teased out in previous treatments. Not least, this is because they are examined and expressed in rather different ways in different literatures”. Corporate identity, for example, has strong practitioner roots and its theoretical base is somewhat underdeveloped (He and Balmer, 2007). In so being, marketing and communication literatures tend to be qualitative and tend to document changes in the artifacts and other material manifestations of corporate identity that occur in response to historical and other fluctuations in market conditions and forces (Cornelissen et al., 2007). In contrast, organizational literature has typically been explored in archival case studies which identify variability in people's representations of organizational identities as a function of situational and strategic concerns (Cornelissen et al., 2007).

All in all, there has been little in the way of cross-fertilization of ideas between these welldeveloped bodies of literature so far (Hatch and Schultz, 1997; Balmer and Wilson, 1998) and disciplinary perspectives have been generally considered to negate the others (Balmer, 2008). Nevertheless, the benefits of integrating perspectives have started to gain momentum and a new line of research has developed to solve the problems derived from the disconnection in literature (He and Balmer, 2005, 2007; Balmer, 2008). Current concerns regarding the integration of different perspectives in the study of business identity are well represented in the following quote by van Rekom et al. (2008):

"(...) the integration of scholarly work rooted in different traditions has not always been (as) smooth. In spite of extensive cross-citation, different understandings of the concept seemed to co-exist, reflecting different philosophical, epistemological and methodological perspectives. Unfortunately, 
these differences were seldom fully acknowledged or effectively handled, leading to conceptual confusion and, worse, empirical uncertainty”

In this paper, the goal of the authors is to provide a comprehensive and integrative overview of academic literature analyzing identity in business. In our paper we follow Balmer’s (2001a) terminology and we chose business identity as a global label to refer to the integrative perception of identity in corporations. This way we aim to avoid confusion between the global identity depicted here and what we consider specific dimensions of identity (organizational personality- and corporate -symbolism, behavior and communications- identities) which have been extensively referred by previous scholars. For the purpose of the paper we revise theoretical, empirical and managerial contributions from the organizational behavior and marketing literatures in order to identify the most significant patterns of study which are useful to provide a simple yet comprehensive framework integrating proposals from both streams. In so doing, we aim to help clearing up theoretical and practical understanding of this concept so managers can easily and effectively understand, identify and manage all the components of their business identities. Actually, the adequacy of these kinds of frameworks to the managerial field has been long declared by academics when they consider that " $a$ powerful explanatory framework now requires scholars to recognize differences across perspectives and work to show how the different perspectives can be used together to provide a more complete picture of this complex phenomenon" (van Rekom et al., 2008). For example, Balmer applies a combined study of organizational and corporate identity to most of his papers and he provides one of the most appealing approaches to the understanding of identities in businesses (Balmer, 1998, 2008; Balmer and Greyser, 2003). The proposal of Cornelissen et al. (2007) is to integrate the understanding of social identity, organizational identity and corporate identity to advance knowledge of corporate processes, patternings and 
product decisions. These authors even specify that “(...) whereas in the past these fields tended to exist (and could be advanced) quite independently, there is now value in -and indeed a pressing need for- interdisciplinary cross-fertilization”. Schultz et al. (2000) believe that without addressing the question of integration, we run the risk of propagating a highly fractionated Babel-esque view of intra- and extra-organizational identity processes and their manifestations. "Moreover, a limited appreciation of the links across disciplinary perspectives is likely to prove inefficient and unparsimonious as researchers fail to take advantage of theoretical and empirical progress in other areas and simply 'rediscover' what is known already" (Cornelissen et al., 2007).

Our literature review is presented as follows. First, academic perspectives defining organizational and corporate- identity are revised. The proposal of an integrative framework to understand identity in the business sphere is also reviewed (e.g., He and Balmer, 2005, 2007; Balmer, 2008). Thirdly, the diverse dimensions of this global concept are detailed. Finally, the conclusions derived from this study are included.

\section{Identity in organizational literature}

First, it is considered that "the mere mention of the word identity would suggest that this subject is especially appropriate to the fields of organizational behavior and psychology" (Melewar and Wooldridge, 2001). As a consequence, the most significant literatures contributing to the development of the organizational identity concept are organizational behavior, organizational theory and strategic management (Ravasi and van Rekom, 2003). In these literatures, identity has traditionally had an internal/employee orientation (Balmer, 
2008) where organizational identity refers broadly to what members perceive, feel and think about their organizations (Hatch and Schultz, 2002).

This internal/employee orientation is also easily perceived in the two dominant perspectives which study organizational identity. In this regard, there exists a first stream of opinion where researchers and practitioners consider that the design and implementation of organizational identity should be an answer to the question "who are we as an organization” (Brown et al. 2006; Price et al., 2008). This proposal takes from Albert and Whetten’s (1985) definition that considers a tripartite formulation to understand organizational identity. According to these authors, identity combines (a) all the features that are somehow seen as the essence of the organization (claimed central character), (b) all the features that distinguish the organization from competitors (claimed distinctiveness) and (c) all the features that exhibit some degree of sameness or continuity over time (claimed temporal continuity). This proposition represents the first milestone in strategic management literature related to identity and, as so, it has been widely accepted and applied by many researchers ever since.

Nevertheless, with the increase of its popularity the paper by Albert and Whetten (1985) has also gained detractors which have led to the proposal of a second line of thought regarding organizational identity (Gioia et al., 1994, Ravasi and van Rekom, 2003). Based on this perception, van Rekom et al. (2008) perceive that "as research on organizational identities intensified, however, the fundamental richness, as well as the relative ambiguity, of Albert and Whetten's early treatment of the concept opened the way for the development of new interpretations, rooted in different disciplinary and epistemological traditions”. Most of the critics refer to Albert and Whetten's consideration of identity as corporate claims embedded in management vision and corporate mission statements, strategy and communications. 
However, detractors refer to organizational identity as a common understanding, shifting the attention from what is explicitly stated to the set of shared cognitive structures of organizational members (Gioia et al., 1994; Ravasi and van Rekom, 2003).

In tune with these critics, Whetten (2006) revises their initial definition to clarify its meaning. In so doing, he gives a specific name to each of the components in the original definition, now named: (a) ideational, (b) definitional and (c) phenomenological. The ideational component equates organizational identity with members' shared beliefs regarding the question "who are we as an organization?”. The definitional component proposes a specific conceptual domain for organizational identity, characterized as the central, distinctive and enduring (CED) features of an organization. Finally, the phenomenological component posits that identityrelated discourse is most likely to be observed in conjunction with profound organizational experiences. In this new paper, Whetten (2006) also points to the possible reason for the misunderstanding of their first definition:

"Looking back, it is my sense that the present lack of conceptual clarity in the literature citing this foundational article is largely due to the increasingly common practice of treating the ideational part of our tripartite formulation as if it were the whole, and thus treating the whole as if it were its least-discriminating part”.

Thus, this second perspective thinks of organizational identity as managers' and employees’ response to "who do we want others to think we are as an organization?" (Brown et al. 2006; Price et al., 2008). According to this line of thought, identity is considered as an interpretative system of shared meaning or cognitions, language and behaviors (Cornelissen et al., 2007; 
van Riel and Fombrun, 2007), that is, how members conceive the identity of their organization. These authors define identity as everything that formal members of the company think and feel about it, which is derived from the perception of the CED characteristics of the organization. According to this definition, identity is a means of expressing what Abratt (1989) labels corporate personality, that is, the set of essential features that gives individuality and differentiates an organization.

In this regard, according to Ingenhoff and Fuhrer (2010) one possible way to describe a company is by the use of personality and character attributes, a widely accepted line of research label "the human metaphor" (Gorb, 1992; Davies et al., 2001; Chun and Davies, 2001; Okazaki, 2006; He and Balmer, 2007). These authors consider that brands can have personality and they can be described based on human characteristics (Gioia, 1998; Cornelissen and Elving, 2003; Whetten, 2006; He and Balmer, 2007). In this regard, corporate personality is defined as "the set of human characteristics associated with a brand" (Aaker, 1997). Ingenhoff and Fuhrer (2010) consider that the human metaphor is the best way to conceptualize the complexity of an organization reflected in brand personality attributes.

Based on these ideas, a third significant line of research in organizational literature is the one which proposes a close connection among organizational identity, personality and corporate identification. In this regard, Cornelissen et al. (2007) consider that "organizational identity is seen as a self-definition or cognitive self-representation adopted by organizational members (...) and refers to those features that are perceived as ostensibly central, enduring, and distinctive in character (and) that contribute to how they define the organization and their identification with it”. The relevance of this research field lies in its fundamental role as a concept that affects both employees' satisfaction and corporate effectiveness (Brown 1969; 
Hall et al., 1970; Ashforth and Mael, 1989). Based on psychological proposals, several authors have linked this identification process with the construction of the collective social identity of businesses which is draw on social identity (Tajfel and Turner, 1979), selfcategorization (Turner et al., 1987) and organizational identity theories (Ashforth and Mael, 1989).

These approaches attempt to explain group processes and intergroup relations resulting from an individual's social position. For example, according to social identity theory (Tajfel and Turner, 1979, 1986; Tajfel, 1984; Turner, 1982, 1991; Turner et al., 1987; Brewer, 1991; Hogg et al., 1995; Hogg and Abrams, 1998; Ellemers et al., 1999), people tend to classify themselves and other individuals within social groups to better understand their social reality (Tajfel and Turner, 1979). According to Marín and Ruiz (2007), these categories or social groups are formed from the identifying features of their members (Ashforth and Mael, 1989), who are emotionally involved in the group and perceive a degree of similarity with the other members in the category. This knowledge facilitates the cognitive and affective identification. Moreover, membership in a social category or group allows the individual to be defined in terms of the characteristics that define the group (Tajfel 1978; Hogg and Abrams, 1998). Thus, the decision to join a group is determined by the emotional significance and value that the categorization brings to the subject.

In this line, the core of social identity theory is built around three basic concepts: categorization, identification and comparison. To produce an individual's identification with a social group, Ellemers et al. (1999) suggest that it is important to combine the three components of identity, which represent each of these concepts: (1) a cognitive component corresponding to the categorization process, which involves the cognitive certainty of 
belonging to a social group (self-categorization), (2) an emotional component, corresponding to the individual's emotional involvement in the group, which relates to the concept of identification (affective commitment) and (3) an evaluative component, related to comparison, which suggests a positive value given by the individual to group membership (group self-esteem). Therefore, to produce a genuine identification requires not only the individual's self-categorization in the social group but also the existence of an emotional feeling and commitment to membership (Branscombe and Wann, 1994; Doosje et al., 1995, Ellemers and vanRijswijk 1997; Ellemers et al., 1999).

Self-categorization theory (Turner et al., 1987; Oakes et al., 1993; Hogg and Terry, 2000) is closely associated with this first approach and may be considered a detailed extension of it (Hogg and Terry, 2000). Specifically, where social identity theory focuses on the effects of identification on intergroup processes, self-categorization theory focuses on intra-group phenomena. The latter develops in detail the process of categorizing individuals, the first stage of social identity theory, as a basis for group behavior. Thus, self-categorization theory helps to explain the reactions and behaviors of the individual as a member of a social group and the mechanisms underlying those behaviors. Thus, the categorization process accentuates the perceived similarities among physical or personal stimuli in the same category and differences observed with respect to stimuli belonging to other categories (Hogg et al., 1995).

Finally, based on the principles of social identity theory, many researchers have developed models to explain the process of identifying individuals with business organizations in what is known as the organizational identity theory (Ashforth and Mael, 1989; Mael and Ashforth, 1992; Dutton et al., 1994; Bergami and Bagozzi, 2000; Marín and Ruiz, 2007). Organizational identity can be understood as a kind of social identification (Ashforth and Mael 1989; 
Cornelissen et al., 2007) that represents the degree to which subjects identify themselves with the most representative attributes that characterize the firm (Dutton et al., 1994; Lichtenstein et al., 2004). These characteristics derive from the corporate mission, structure, processes and climate (Bhattacharya and Sen, 2003). Therefore, this concept refers to the feeling of overlap between self-perception and the perception of the company (Belch and Belch, 1987). This sense of belonging and connection to an organization is how a person achieves a positive social identity (Bergami and Bagozzi, 2000; Kreiner and Ashforth, 2004). As a result of this sense of connection, the organization is psychologically accepted as part of the personal identity (Scott and Lane, 2000).

The connection between organizational identity and identification is well represented in He and Balmer's (2007) work. These authors identify four identity perspectives -visual identity, corporate identity, organization's identity and organizational identity- which differ with regard to conceptualization, locus of analysis and research foci. The first two relate to identity studies in the marketing field while organization and organizational identities are underpinned in organizational behavior literature. According to the proposals of these authors, "in contrast to organization's identity, which refers to the identity of an organization, "the identity of people within an organization”, which is normally called organizational identity should be 'an individual's social identity within an organizational context. (...)”. Individuals also have a personal identity (who I am), as well as a social identity (social category membership or role) (Tajfel and Turner, 1986; Ashforth and Mael, 1989). Finally, the connection is also perceived in Balmer's (2008) proposal of the “quindrivium”. This concept, which literally means "the place where five roads meet", can be characterized as the conjunction of (a) corporate identity (the identity of the organization); (b) communicated corporate identification (identification from the organization); (c) stakeholder corporate identification (an individual, 
or stakeholder group's, identification with the organization); (d) stakeholder cultural identification (an individual, or stakeholder group’s, identification to a corporate culture); and (e) envisioned identities and identifications (this is a broad category and relates to how an organization, or group, envisions how another corporate or group characterizes their identity or mode of identification).

\section{Identity in marketing literature}

On the contrary, corporate identity has a more overt external, customer/stakeholder orientation (Balmer, 2008) and is usually equated with the projected image of the company (Cornelissen et al., 2007). In this research field also two perspectives have been traditionally applied to the study of identity.

First, identity studies in marketing begin with Lippincott and Margulies (1964, in He and Balmer, 2007) who define corporate identity as the visual image through which the company presents itself to its various stakeholders (Christensen and Askegaard, 2001; van Riel and Fombrun, 2007). This idea is further advanced by authors such as Selame and Selame (1975), Olins (1978, 1989), Carter (1982, in van Riel and Fombrun, 2007) or Schmidt (1996). Thus, the first definitions of the concept consider that businesses convey their identity primarily through their logos, brand images and any other visual manifestations of the organization (Selame and Selame, 1975; Carter, 1982). In this regard, corporate identity stems from early work in the field of graphic design (Olins, 1978, 1989; Chajet and Schatman, 1993; Schmidt, 1996) where it is related to factors influencing organizational graphics and imagery that are used to encompass and portray an organization's characteristics to the outside world (Balmer, 1994; Melewar and Wooldridge, 2001). 
However, the conceptualization of corporate identity has evolved from this first type of definitions, especially focused on peripheral elements of the organization, towards conceptualizations focused on corporate core elements such as strategy and communication (Balmer, 1994). Balmer and Wilkinson (1991) identify a school of thought which places less emphasis on design and sees corporate identity as being more an organic process. "Corporate identity is seen to be of strategic importance and marketing-based” (Balmer and Wilkinson, 1991). This fact leads to the second line of though in the marketing literature; label the “corporate communication” perspective. This is a more accepted stream in recent literature which considers that corporate identity is more than corporate names and logos (Melewar et al., 2006). This approach reviews how certain attractive features of the company's identity can be also transmitted through behavior or verbal communications that the company uses to relate to its stakeholders. In this regard, Balmer (1995) and Balmer and Wilson (1998) believe that the different schools of thought do not represent mutually exclusive approaches to corporate identity but, rather, they suggest that "there should be an integrated, multidisciplinary approach, of which graphic design is only one element” (Balmer and Wilson, 1998). Furthermore, van Riel and Balmer (1997) conclude that corporate identity is generally equated with (1) graphic design, (2) integrated corporate communication, and (3) a multidisciplinary approach that draws heavily on organizational behavior.

According to the latest ideas from the marketing perspective, then, corporate identity is constructed through both symbolic and behavioral communication (van Riel and Fombrun, 2007). Holtzhausen and Fourie (2008) consider that definitions of corporate identity range from those only including visual design elements to those including all aspects of the company's self-presentation, including all physical and behavioral aspects that distinguish 
one company from another. These ideas lead to the presentation of the "identity mix" concept, initially proposed by Birkigt and Stadler (1986), which refers to the set of attributes that stakeholders might use to describe a company (van Riel, 1995; van Riel and Fombrun, 2007). In the initial identity mix of Birkigt and Stadler (1986), corporate communication, behavior and symbolism are included as the most common tools to express the personality of the company (van Riel, 1995, Melewar and Storrie, 2001; Cornelissen and Elving, 2003; van Riel and Fombrun, 2007).

\section{The integrative approach to the study of identity}

In spite of the differences between organizational and corporate identities, a new school of thought proposes an integrative framework for the study of identity in business, where each of the proposals of organizational behavior and marketing approaches provides useful information to build the knowledge regarding the components of this complex concept. Thus, authors following this line of thought consider that efforts should be applied to the combined analysis of both literatures which could assist us in fully understanding this concept (Melewar and Jenkins, 2002; Hatch and Schultz, 2002; Balmer and Greyser, 2003; Kim and Hatcher, 2009).

He and Balmer (2007) believe that the cross-fertilization has already started, as represented in two convergences between literatures. The first convergence can be seen with regard to the mutual recognition of the marketing and organizational behavior approaches to identity studies. The second convergence relates to the emerging dialogue between marketing and organizational scholars, "especially through venues of identity conferences and special issues on identity studies” (He and Balmer, 2007). 
According to He and Balmer (2007), mutual contributions from a range of disciplines have been taken into account in an attempt to link social, organizational and corporate identity theories (Kim, Hatcher 2009). In this regard, several authors have shown that organizational and corporate identity are not opposites, but are closely related concepts, corporate identity being an explicit form of transmission of organizational identity (Christensen and Askegaard, 2001; Dhalla, 2007; Cornelissen et al., 2007). As so, while social identity tends to be seen as an internalized knowledge structure, organizational identity is perceived as a system of shared meaning and corporate identity tends to be seen as the projected image of that shared cognition and feeling (Cornelissen et al., 2007). Cornelissen et al. (2007) further explain the connections among the three identities. First, social identity reflects the internal, cognitive factors which lead employees' to identify with the organization. On the other hand, corporate identity has traditionally placed the emphasis on external, symbolic factors (material manifestation of identity). Finally, organizational identity seems to move between these two traditions since it reflects a concern with both the internal and external dimensions of identity. This time organizational identity addresses the patterning of social and corporate meanings and "the way they are negotiated within the dynamic interactions of organizational life" (Cornelissen et al., 2007).

In addition to these ideas, the latest definitions propose identity as a broad concept (Cornelissen and Elving, 2003) composed of various dimensions (Melewar et al., 2006; He and Balmer, 2007). For example, Melewar and Jenkins (2002) posit that, firstly, identity is related to reality and what a company is, that is to say, its strategy, philosophy, history, business scope and product and services offers. Secondly, corporate identity is also related to both formal and informal corporate communication (Melewar and Jenkins, 2002). 
Otubanjo and Melewar (2007) align with this proposal when they group the conceptual approaches to identity (Table 1) in such a way that all of them converge in the dimensions of corporate personality and identity mix. For instance, according to these authors the culture (Moingeon and Ramanantsoa, 1997), organizational reality (Cornelissen, 2000), collective OI perspective (He and Balmer, 2005) and strategy school of thought (Balmer, 1995) are drawn together and interpreted as corporate personality. Regarding the identity mix of corporate communication, the visual behavioral, strategic visual and design schools of thought, the graphic design paradigm and the visual identity perspective are interpreted as symbolism. Similarly, the behavioral school of thought, organizational culture and collective organizations perspective are interpreted as behavior. Finally, the integrated corporate communications school of thought and corporate communications school of thought are interpreted as corporate verbal communications.

Table 1. Conceptual theories of corporate identity

\begin{tabular}{|c|c|c|}
\hline References & Perspective & School of thought \\
\hline Balmer (1995) & $\begin{array}{l}\text { Seven schools of } \\
\text { thought }\end{array}$ & $\begin{array}{l}\text { (1) Strategic; (2) Strategic Visual; } \\
\text { Behavioural; (4) Visual Behavioural; } \\
\text { Corporate Communications; (6) Strategic } \\
\text { Communication; (7) Design Fashion }\end{array}$ \\
\hline $\begin{array}{l}\text { van Riel and } \\
\text { Balmer (1997) }\end{array}$ & $\begin{array}{l}\text { Three perspectives } \\
\text { in the study of } \\
\text { identity }\end{array}$ & $\begin{array}{l}\text { (1) Graphic design; (2) Integrated corporate } \\
\text { communications; (3) Interdisciplinary }\end{array}$ \\
\hline $\begin{array}{l}\text { Moingeon and } \\
\text { Ramanantsoa } \\
(1997)\end{array}$ & $\begin{array}{l}\text { French school of } \\
\text { thought }\end{array}$ & $\begin{array}{l}\text { (1) Corporate personality; (2) Culture } \\
\text { Definition of corporate identity }\end{array}$ \\
\hline $\begin{array}{l}\text { Leitch and Motion } \\
\text { (1999) }\end{array}$ & $\begin{array}{l}\text { Traditional } \\
\text { approach vs. } \\
\text { Postmodern theory }\end{array}$ & $\begin{array}{l}\text { (1) Traditional approach (corporate identity } \\
\text { theory); (2) Postmodern theory }\end{array}$ \\
\hline $\begin{array}{l}\text { Cornelissen } \\
(2000)\end{array}$ & $\begin{array}{l}\text { Three metaphorical } \\
\text { perspectives }\end{array}$ & $\begin{array}{l}\text { Corporate identity as (1) an expression of } \\
\text { corporate personality; (2) organizational reality; } \\
\text { (3) all the expressions of a company }\end{array}$ \\
\hline $\begin{array}{l}\text { He and Balmer } \\
(2005,2007)\end{array}$ & Five perspe & $\begin{array}{l}\text { (1) Visual identity; (2) Corporate identity; (3) } \\
\text { Multidisciplinary identity; (4) Collective OI; (5) } \\
\text { Organizational identification }\end{array}$ \\
\hline
\end{tabular}

Source: Compiled by author based on Otubanjo and Melewar (2007) 
These ideas reflect the traditional identity-mix proposed in marketing literature, strongly rooted in Birkigt and Stadler's (1986) work. Citing Balmer (2002), “to date, the most influential corporate identity mix has been that of Birkigt and Stadler (1986). The component parts of their mix consist of corporate personality, behavior, communications, and symbolism”. Nevertheless, and based on the philosophy of the integrative approach, Balmer and Soenen (1999) revise the original proposal to also include three new dimensions stakeholders, reputations and environment- closely related to the management of the marketing identity-mix defined by Birkigt and Stadler (1986). Actually, He and Balmer (2007) consider that the biggest advances in the multidisciplinary approach has not been so much given by the impact that marketing has made on the organizational behavior literature but those provided by the contributions of the latter on the former. This proposal is also based on Balmer's identification of several discrepancies between the mix of elements comprising corporate identity at the academic level and the mix reflected in many models of corporate identity management. Managers are especially interested in these three new dimensions of the mix which are closely related to the practical elements required for the management of identity in the business realm. As so, Balmer and Soenen (1999) define this second identity mix as the "corporate identity management mix". Thus, the understanding of these dimensions is essential for both academics and practitioners. Balmer (2002) advances on these ideas as it will be presented in the following section of this paper.

\section{The components of identity in business}

Defining the dimensions of identity has been a traditional goal pursue by academics both in the organizational and marketing field (Kim and Hatcher, 2009). In this regard, the ambiguity 
regarding the elements that constitute identity in business is considered one of the most significant problems which the development of common understanding has encountered in this research arena (Balmer, 2002).

Nevertheless, for years authors have accepted Birkigt and Stadler's (1986) definition of the “corporate identity mix”, with a strong marketing orientation, where corporate personality and behavior, communication and symbolism are the common dimensions called upon (van Riel, 1995). Only recently researchers have started to consider other proposals which extend the mix to also include the organizational behaviorists’ ideas about business identity (Balmer and Soenen, 1999; Balmer, 2002; Melewar and Jenkins, 2002; He and Balmer, 2007).

One of the most comprehensive proposals among the latter is the one of Balmer and Soenen (1999), further developed by Balmer (2001a, 2002) and He and Balmer (2007). These authors consider that the proposal of Birkigt and Stadler (1986), tough interesting for the purpose of simplicity in articulation, does not reflect all the facets which managers have to deal with when defining and developing their business identities. Actually, a lack of distinction seems to exist between "the elements comprising (corporate) identity and the mix of elements required of its management” (Balmer, 2002). In this regard, “an organization's identity may be anchored in some specific combination of geographical place, nationality, strategy, founding, core business, technology, knowledge base, operating philosophy or organization design” (Cornelissen et al, 2007). Balmer (2008) identifies a growing number of researchers focusing on traits encompassing strategy, structure, history and culture (Balmer, 2001a; Melewar and Karaosmanoglu, 2006; Cornelissen et al., 2007). All this organizational issues are encompassed in a second identity mix: the "corporate identity management mix". The 
philosophy and components of the different mixes proposed in literature are represented in

Figure 1 and explained in the subsequent sections of this paper.

Figure 1. The "corporate identity mix" and the "corporate identity management mix"

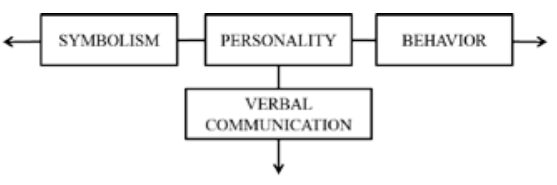

Birkigt and Stadler’s “corporate identity mix"

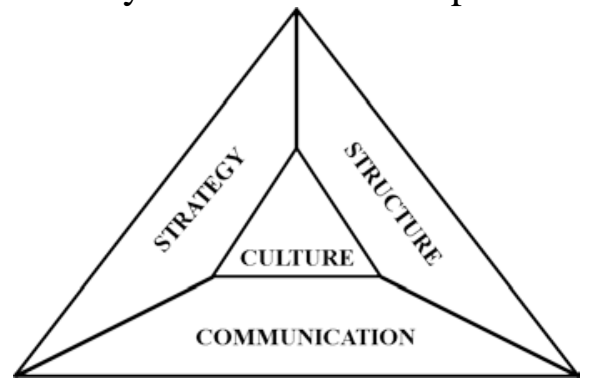

Balmer's “corporate identity mix”

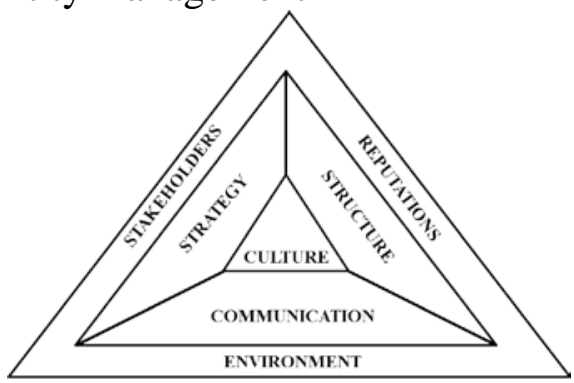

Balmer's “corporate identity management mix"

Source: Based on Birkigt and Stadler (1986) and Balmer (2002)

Corporate identity mix

First, the corporate identity mix is compounded of the organization's: (a) soul (core values, cultures, internal images, employees affinities and history); (b) mind (vision and philosophy, strategy, products and services performance, corporate performance, brand architecture, corporate ownership) and (c) voice (controlled communication, non-controlled communication, symbolism, personnel and corporate behavior, indirect communication) (Balmer and Soenen, 1999).

Both the "soul” and "mind" of the organization are closely related to corporate personality (Olins, 1978; Abratt, 1989; Stuart, 1999). As previously anticipated, the human metaphor considers that brands can be perceived as possessing personality features (Davies et al. 2001) and defines corporate personality in terms of the features of human personality that are pertinent to the brand. So, corporate personality refers to "the soul, the persona, the spirit, the culture of the firm" (Otubanjo and Melewar, 2007). Balmer (1995) argues that corporate 
personality refers to the mix of cultures present within the organization and many researchers consider that the corporate personality is at the heart of an organization's corporate identity.

Otubanjo and Melewar (2007) revise the concept and highlight how researchers on the managerial field consider that corporate personality "is determined before the formation of the organization" (Abratt, 1989). According to these authors, "internal and corporate personality reflects who or what the organization is, where it is going, how it is different, what it does, how it carries out its business and what it stands for". Thus, it is formed by the culture that the organization adopts and by the internal characteristics of the organization that define the essence of the firm. According to Abratt (1989), corporate personality is made of the characteristics that differentiate the company and make it unique. These characteristics include corporate strategy and philosophy which "personify the internalities of the firm" (Otubanjo and Melewar, 2007).

Nevertheless, personality is quite a complex concept which (Balmer 2002) splits into three sub dimensions:

Strategy: consists of (a) management vision and corporate philosophy, (b) corporate strategy, (c) the performance of products/services and corporate performance, (d) corporate brand covenant; "a defining set of corporate values which the organization promises to maintain and deliver” (Balmer, 2002) and (e) corporate ownership.

Structure: consists of the organization chart and the relationships among the diverse business units, subsidiaries and franchise partners.

Culture: consists of the mix of subcultures present within the organization (corporate, national, regional and professional subcultures). 
Regarding formal instruments where corporate personality is represented, Stuart (1999) considers that corporate personality "embodies the corporate mission, corporate philosophy and core values of the organization” (Powell et al., 2009). Furthermore, researchers also include the vision statement as another important medium for conveying corporate personality and emphasizing uniqueness and difference (Ingenhoff and Fuhrer, 2010). In this regard, many authors refer to the vision-driven approach as referring to corporate mission and vision statements, corporate values and corporate philosophy as the basis of corporate identity management (Balmer and Soenen, 1999; Ingenhoff and Fuhrer, 2010).

Furthermore, the organization's "voice" refers to the traditional mix of communication identified in the marketing literature (van Riel, 1995). In this regard, corporate communication has always been linked to research on corporate identity, because the transmission of corporate personality is considered a key element that contributes to the generation of corporate image (Deegan et al., 1999). Thus, even the researchers who link corporate identity only to the characteristics that describe the firm (Albert and Whetten, 1985; Fombrun, 1996; Christensen and Askegaard, 2001; Fombrun and van Riel, 2004) recognize that for these attributes to be accepted, both internally and outside the organization, the company has to especially take care of the transmission of identity to its target groups (van Riel and Fombrun, 2007).

The communication mix refers to all the means that a company uses to reveal its corporate personality (van Riel and Balmer, 1997). Such means are basically resumed in the corporate symbolism, behavior and communication (Birkigt and Stadler, 1986; van Riel and Balmer, 1997). 
First of all, symbolism refers to visual expressions of an organization (Karaosmanoglu and Melewar, 2006), which include the corporate visual identity system -logo, name, slogan, colors and typography-, corporate aesthetics -architecture, interior design or furniture- and the staff's appearance -implementation of corporate aesthetics to employees' appearance(Melewar and Jenkins, 2002; Karaosmanoglu and Melewar, 2006). This symbolism plays an important role in the transmission of corporate identity, as it has been proved that the roots of corporate identity are found in corporate graphic design (van Riel and Balmer, 1997; Melewar and Saunders, 2000). However, no company can achieve individuality only with design, since individuals use all senses to form an overall picture of an object. Accordingly, management should pay attention to other aspects of corporate identity, including verbal communication and behavior.

In this sense, among all the ways of communicating corporate personality, it is generally considered that the performance of the organization is the most effective, since stakeholders tend to judge the company mainly for their actions (Birkigt and Stadler, 1986; van Riel and Fombrun, 2007). Melewar and Jenkins (2002) consider corporate behavior as the non-verbal and intangible part of communication, including all the actions undertaken by the company and its employees. Likewise, van Riel and Fombrun (2007) consider that this dimension is made up of all behaviors and initiatives supported by the company. Specifically, this means of personality transmission is made up of two dimensions: corporate behavior itself, which relates to ethical actions, actions for the environment and issues related to employees' recruitment (Karaosmanoglu and Melewar, 2006); and communication policy, which includes the behavior of employees and top managers (Melewar and Jenkins, 2002; Karaosmanoglu and Melewar, 2006). In this line, an increasing number of academics acknowledge that a 
corporate identity refers to an organization's unique characteristics, which are rooted in the behavior of employees (Balmer, 1995; Balmer and Wilson 1998).

Corporate verbal communication, in turn, complements behavior when individuals form a picture of the company (Birkigt and Stadler, 1986) and it is the most tactical and more used tool to transmit corporate identity (van Riel and Fombrun, 2007). In this line, corporate communication is understood as a management tool that uses all ways of internal and external corporate communication in a harmonious, effective and efficient way to generate a base of stable relations with all stakeholders (van Riel, 1995). In contrast to corporate behavior, communication relies on verbal messages (van Riel and Fombrun, 2007) which can be classified into management communication, marketing communication and organizational communication (Melewar and Jenkins, 2002).

Corporate identity management mix

Secondly, the identity of an organization also includes: (d) the management of stakeholders, (e) reputations and (f) the environment of the company (Balmer and Soenen, 1999). This is an augmentation of the corporate identity mix which details the variables and activities that practitioners should consider when they are in charge of the management or change of their organization's identity (Balmer, 2002). A brief explanation of each of these dimensions is included next:

Environment: consists of "political, economic, ethical, social, and technological developments, competition, and the threat of potential entrants" in the organization's 
market (Balmer, 2002). Business identities exist in this context and, as such, managers must learn to deal with all these determinants.

Stakeholders: consists of the number, type and mix of stakeholders an organization is responsible to. "Effective corporate identity management implies that these publics are prioritized, their expectations are understood and, as far as the exigencies of the situation warrant, met” (Balmer, 2002).

Reputations: consists of the reputations of the CEO, key members of the management board and the industry in which the organization operates. Since business identity is a global concept, individual identities inside the company -and those outside the organization but closely related to it- must be known and manage to avoid harm and to take advantage of their most positive attributes.

The $A C^{4} I D$ Test

Finally, it should also be noticed that all the above ideas and identity dimensions are generally analyzed in empirical research from the point of view of only one category of business identity: the communicated identity (Balmer and Soenen, 1999). Such an identity encapsulates how the organization communicates and how it is perceived by its publics. Such a reality might derive directly from the scarce possibilities that researches have to effectively identify other categories of identity, such as the real or actual identity, which are embedded in more complex mechanisms of the organization. We can also argue this reality by resorting to some of the first identity proposals in the organizational behavior literature. Albert and Whetten (1985) definition of organization identity refers to this concept as the "set of claims" through which a company presents itself and its identity, often encapsulated in corporate values, mission and vision statements. A second line of thought in the organizational literature 
moves one step further to also include employees' perceptions and shared cognitions, emotions and beliefs regarding the company that sponsors those communications. At the same time, marketing academics approach identity from the point of view of its communication, alluding again to the communicated identity category.

Nevertheless, as it usually happens with corporate images, what managers desire for their organizations is not always well represented in corporate behaviors and communications, a fact which leads to significant gaps in the achievement of corporate goals. The message does simply not get through. As so, not only dimensions of business identity have been proposed in academic literature; researches have also pointed to the existence of different kinds or categories of organizational and corporate identities.

In this regard, the ACID test (Balmer and Soenen, 1999; Balmer, 2001b, 2005; Balmer and Greyser, 2003; Balmer et al., 2009) is a tool specially developed for managers to identify connections and gaps among different kinds of identities in order to design more effective strategies. Balmer and Soenen (1999) initially proposed four types of identity: (a) the actual identity, (b) the communicated identity, (c) the ideal identity, and (d) the desired identity. In a later revision of this proposal, Balmer and Greyser (2003) include two new categories: (e) the conceived identity and (f) the corporate brand identity. According to He and Balmer (2007), "these six identities represent the six forces impinging upon any corporate entity, which are reality, communication, perception, strategy, vision, and the promise contained within the corporate brand". The current version dates back to 2005 and comprises seven dimensions of identity (The AC ${ }^{4}$ ID Test) (Balmer et al., 2005). Balmer (2012) has also recently referred to this latest review in order to more clearly define the "Corporate Brand Constellation" of business identities (Table 2). 
Finally, this perspective of the $\mathrm{AC}^{4} \mathrm{ID}$ test is also referred by Balmer in his 2008 paper in the European Journal of Marketing (Balmer, 2008). In this contribution, the author theoretically introduces the notion of "identity-based views of the corporation" which complements the myriad of identities present among corporations and their stakeholders. The reasoning behind the concept lays in the fact that it is potentially very dangerous to consider individual identities of the $\mathrm{AC}^{4} \mathrm{ID}$ test in isolation from each other so the connections between terms should also be taken into consideration (for a complete description of this term see Balmer, 2008). Also, because corporations have increased their concern about their image and reputation, and perception can translate into behavior, construed images or "beliefs about beliefs” (Balmer, 2008) are concepts closely related to corporate and organizational identities. Based on this idea, "envisioned identities and identifications" are proposed by Balmer to complete the brand constellation of business identity (Table 2). 
Table 2. Dimensions of the AC ${ }^{4} \mathrm{ID}$ Test and identity based views of the corporation (the Corporate Brand Constellation)

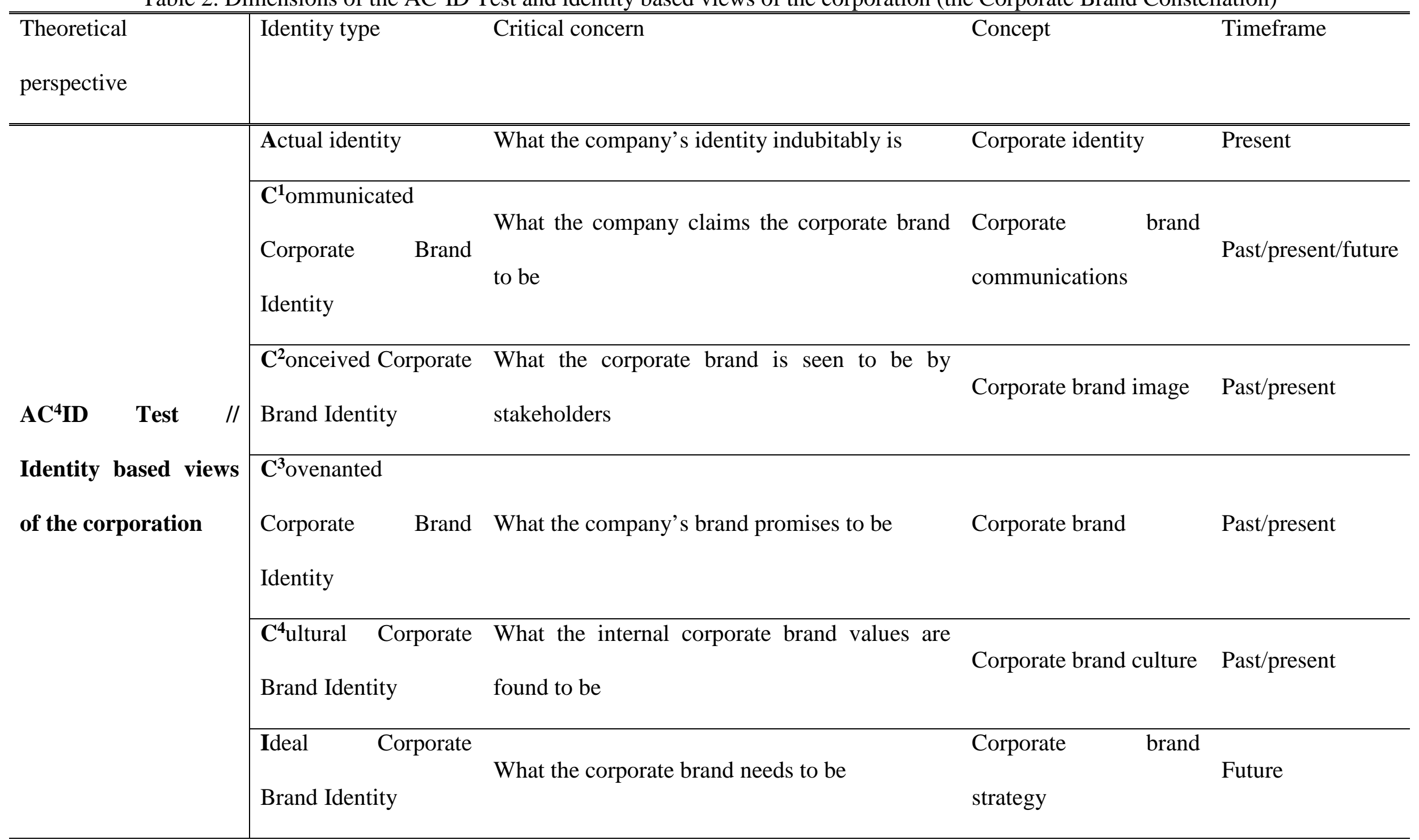




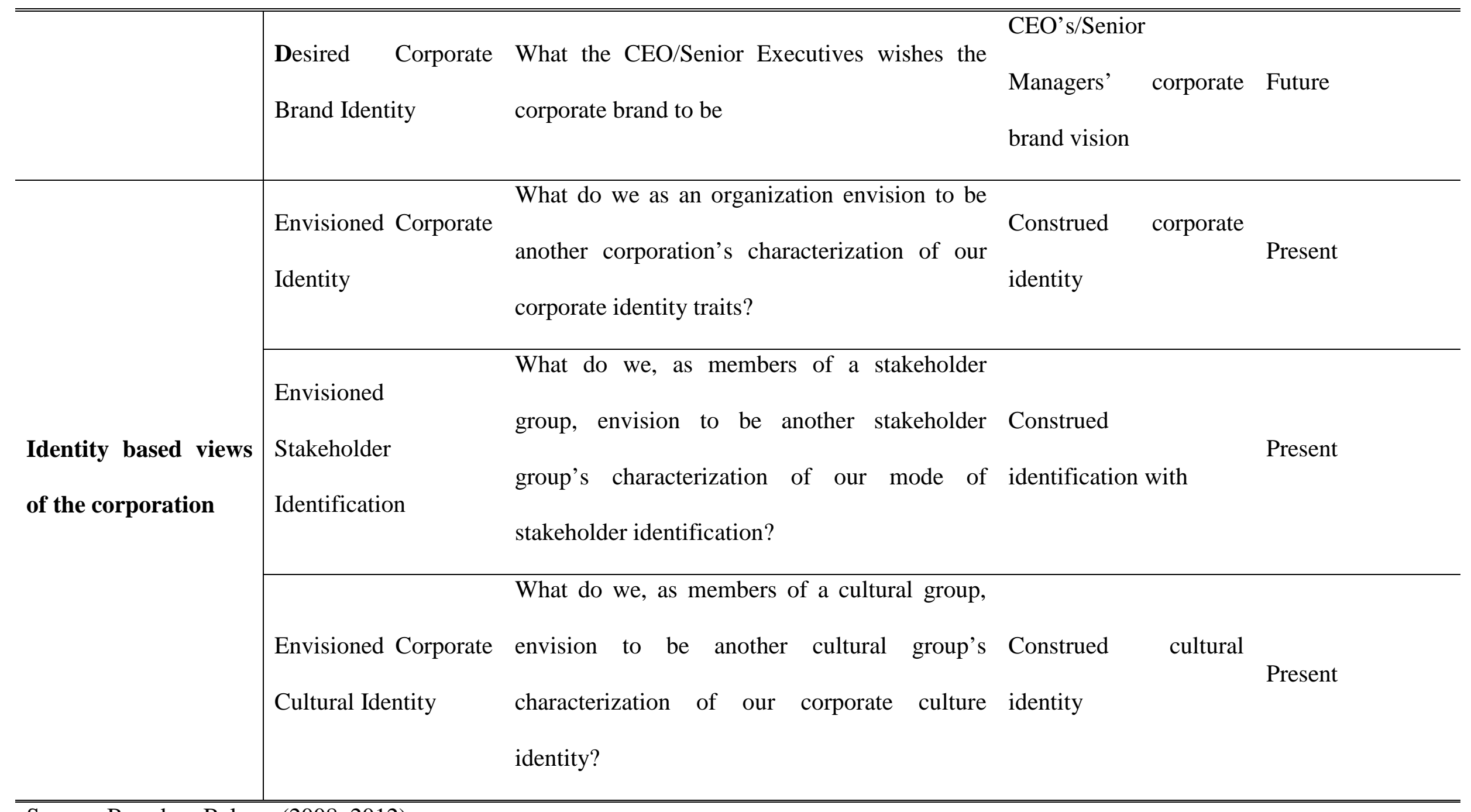

Source: Based on Balmer (2008, 2012) 
The foundations of the AC $\mathrm{AD}^{4}$ test are also based on Balmer and Soenen's (1999) perception that there exists a dichotomy between the latest advances in academic identity literature and managerial applications of this concept. On the one hand, scholars tend to focus on the question "what is an organization's actual corporate identity?" whereas managers and businesses perceive identity as the answer to "how do we communicate an organization's desired corporate identity?” (Balmer and Soenen, 1999). Furthermore, in the latest revision of the test, Balmer (2012) considers that differences also exist in the corporate identity understanding if a time-based perspective is adopted. In this regard, "earlier versions of the $A C^{4} I D$ test were informed by a centrifugal rationale. Multiple identity types should be in alignment with each other. The $A C^{4} I D$ test framework outlined here is underpinned by a centripetal logic. Here, the multiple identity types are required to be calibrated with the covenanted identity. Another difference with the latest model is that greater cognizance is accorded to the temporal dimension. For this reason, the framework has been adapted to cover the future as well as present time frames” (Balmer, 2012) as opposite to previous proposals of the model, which only accounted for the past. A brief explanation of each level of identity is included next:

Actual identity: it refers to the reality of what the organization is. Thus, it is connected to how the values held by staff and management are concretely manifested. "It also includes the type and quality of the products and services offered by the organization, the performance of the company, the behavior of employees and corporate behaviors" (Balmer and Soenen, 1999).

Communicated identity: it refers to how the organization is perceived by its publics and how the organization communicates. Thus, this identity represents a dual process. First, "it refers to the corporate reputations held by the organization among its many 
stakeholder groups. Second, it also includes total corporate communication, which refers to both controllable communication (...) and non-controllable communication” (Balmer and Soenen, 1999).

Conceived identity: it refers to perceptual concepts such as corporate image, reputation and branding. It can be defined as “its (the organization's) multi-attribute and overall corporate image and corporate reputation held by relevant stakeholders" (Balmer and Greyser, 2003).

Corporate identity: also referred to as “covenanted identity” (Balmer, 2008), this type refers to the covenant or promise underpinning a business identity. What the brand stands for.

Cultural identity: it refers to "what the internal corporate brand values are found to be” (Balmer, 2012).

Ideal identity: it refers to the optimum positioning of the organization in its markets (taking into consideration its strengths and abilities in addition to environmental considerations). By environmental considerations we refer to competition, industry trends, consumer values, buying behavior, social environment and industry identity.

Desired identity: it refers to the identity of the organization that its management board wishes to acquire. It is closely related to the "vision for the future" of the chief executive. "It lies in the heads and the hearts of the decision makers" (Balmer and Soenen, 1999).

Envisioned corporate identity: all three new levels of identity proposed by Balmer (2008) in his "identity-based views of the corporation" (envisioned identities and identifications) refer to "beliefs about beliefs relating to identity and identification and has its sources in perceptions and cognitions" (Balmer, 2008). All of them are examined in terms of a category of questions proposed by the author. Envisioned 
corporate identity, for example, relates to how members of the corporation envision the perceptions of another corporation about their corporate identity traits.

Envisioned stakeholder identification: it refers to how the corporation envisions the type of identification a particular group has towards it (Balmer, 2008).

Envisioned corporate cultural identity: finally, this type of business identity refers to "how the corporate culture envisions to be the type of identification another corporate culture has towards the first organization” (Balmer, 2008).

\section{Conclusion}

Corporate identity is one of the strategic 6 C's which define the new marketing paradigm proposed by corporate marketing. Thus, its conceptualization has worried researchers since long ago. However, authors have quite often thought of this concept as interwoven with corporate reputation and corporate image which complicates their understanding. Furthermore, diverse research approaches have applied different definitions of identity proposing independent dimensions which have been scarcely integrated for a complete understanding of business identity.

Nevertheless, it has been shown in this paper that an integrative framework reconciling marketing to organizational behavior approaches has been recently developed to help both researchers and practitioners to better understand the concept and mechanics of business identity. In this regard, definitions of organizational identity as the collection of essential, distinctive and enduring corporate characteristics, either factual or perceived by internal members, are extended with marketing ideas, also including communication as an essential 
dimension of identity in business. The integration of both perspectives into a single approach to the study of identity leads to understanding this concept based on the following ideas:

1. First, business identity refers to the CED attributes of the organization (Albert and Whetten, 1985), represented in formal claims of the company.

2. Business identity also includes members' perceptions of the identity of the organization (Brown et al., 2006).

3. These claims and perceptions refer to the company's personality (Abratt, 1989) which encapsulates the 'soul' and 'mind' of the organization, including its strategy, structure and culture (Balmer and Soenen, 1999). Such a personality and, thus, identity too, are communicated by means of a communication mix (Birkigt and Stadler, 1986) that includes symbolism, verbal communication and corporate behavior. The conjunction of both personality and communication is what integrative academics have labeled the “corporate identity mix” (Balmer and Soenen, 1999).

4. Furthermore, a “corporate identity management mix" should also be taken into consideration. This time authors refer to all the variables practitioners should be concerned with in order to effectively manage every dimension of the business identity.

5. The transmission of the business identity to internal audiences of the organization leads to significant benefits for the institution, especially employees' and managers' identification with the collective identity of the company. In this regard, the "human metaphor” (Gorb, 1992), social (Tajfel, 1984), self-categorization (Turner et al., 1987) and organizational (Ashforth and Mael, 1989) identity theories demonstrate that members' of a group -organization, this time- tend to define themselves based on the characteristics of the group, in such a way that the perception of an overlap between 
the personal and collective identities results in a stronger identification with the organization. The identification process finally leads to employees’ satisfaction and, in turn, corporate effectiveness (Ashforth and Mael, 1989).

6. The external communication of business identity helps stakeholders to identify the CED attributes of the organization in such a way that this fact helps the purpose of differentiation from competitors.

7. Also, the AC ${ }^{4}$ ID test (Balmer and Soenen, 1999; Balmer, 2012) assists managers in identifying diverse categories of identity in business. Basically, there are seven possible identities: actual, communicated, ideal, desired, cultural, conceived and corporate brand identity. This management tool has the purpose of identifying possible gaps among identities, in such a way that managers can quickly and easily identify and repair, if necessary, flaws in corporate strategies regarding this concept.

8. Finally, "beliefs about beliefs" (Balmer, 2008) relate business identity to construed/perceived identities, identifications and images. The categories of identity in the $\mathrm{AC}^{4} \mathrm{ID}$ test are completed with envisioned identities which lead to “identitybased views of the corporation" to understand the brand constellation of business identity (Balmer, 2008).

The proposal of this integrative framework for the understanding of business identity presents interesting managerial implications. It reminds practitioners that defining their mission, vision and values statements is not enough for an effective and successful management of identity. An adequate communication of these attributes to society and stakeholders is also necessary. In this regard, everything communicates, which makes it essential for companies to carefully manage internal identity for all formal members of the organization to be identified with the company and, then, be good ambassadors of the corporate philosophy in the external sphere. 
Properly understanding and managing all components of business identity would help businesses to positively influence other corporate marketing concepts such as corporate image, reputation and brand value in the marketplace.

\section{References}

Aaker, J.L. (1997) Dimensions of brand personality. Journal of Marketing Research 34(3): 347.

Abratt, R. (1989) A new approach to the corporate image management process. Journal of Marketing Management 5 (1): 63-76.

Albert, S. and Whetten, D.A. (1985) Organizational identity. Research in Organizational Behavior 7: 263-295.

Alessandri, S.W. and Alessandri, T. (2004) Promoting and protecting corporate identity: The importance of organizational and industry context. Corporate Reputation Review 7(3): 252.

Argenti, P.A. and Druckenmiller, B. (2004) Reputation and the corporate brand. Corporate Reputation Review 6(4): 368-374.

Ashforth, B.E. and Mael, F. (1989): Social identity theory and the organization. The Academy of Management Review 14(1): 20-39.

Balmer, J.M.T. (1994) The BBC’s corporate identity: Myth, paradox or reality. Journal of General Management 19(3): 33-.

Balmer, J.M.T. (1995) Corporate branding and connoisseurship. Journal of General Management 21(1): 24-47.

Balmer, J.M.T. (1998) Corporate identity and the advent of corporate marketing. Journal of Marketing Management 14(8): 963-996. 
Balmer, J.M.T. (2001a) Corporate identity, corporate branding and corporate marketing Seeing through the fog. European Journal of Marketing 35(3/4): 248-291.

Balmer, J.M.T. (2001b) From the Pentagon: A new identity framework. Corporate Reputation Review, 4(1): 11-22.

Balmer, J.M.T. (2002) Of identities lost and found. International Studies of Management and Organization 32(3): 10-27.

Balmer, J.M.T. (2008) Identity based views of the corporation. European Journal of Marketing 42(9/10): 879-906.

Balmer, J.M.T. (2009) Corporate marketing: apocalypse, advent and epiphany. Management Decision 47(4): 544-572.

Balmer, J.M.T. (2011) Corporate marketing myopia and the inexorable rise of a corporate marketing logic. Perspectives from identity-based views of the firm. European Journal of Marketing 45(9-10): 1329-1352.

Balmer, J.M.T. (2012) Corporate brand management imperatives: Custodianship, credibility and calibration. California Management Review 54(3): 6-33.

Balmer, J.M.T. and Wilkinson, A. (1991) Building societies: Change, strategy and corporate identity. Journal of General Management 17(2): 20-.

Balmer, J.M.T. and Wilson, A. (1998) Corporate identity: There is more to it than meets the eye. International Studies of Management \& Organization 28(3): 12-31.

Balmer, J.M.T. and Soenen, G.B. (1999) The ACID test of corporate identity management ${ }^{\mathrm{TM}}$. Journal of Marketing Management 15(1-3): 69-92.

Balmer, J.M.T. and Greyser, S.A. (2003) Revealing the Corporation: Perspectives on Identity, Image, Reputation, Corporate Branding, and Corporate-Level -marketing. London: Routledge. 
Balmer, J.M.T. and Greyser, S.A. (2006) Corporate marketing: Integrating corporate identity, corporate branding, corporate communications, corporate image and corporate reputation. European Journal of Marketing 40(7/8): 730-741.

Balmer, J.M.T., Stuart, H. and Greyser, S.A. (2005) Aligning identity and strategy: Corporate branding at British Airways in the late 20 ${ }^{\text {th }}$ century. California Management Review, 51(3): 623.

Balmer, J.M.T., Powell, S.M. and Greyser, S.A. (2011) Explicating ethical corporate marketing. Insights from the BP Deepwater Horizon catastrophe: The ethical brand that exploded and then imploded. Journal of Business Ethics 102(1): 1-14.

Belch, G.E. and Belch, M.A. (1987) The application of an expectancy value operationalization of function theory to examine attitudes of boycotters and nonboycotters of a consumer product. Advances in Consumer Research 14(1): 232-237.

Bergami, M. and Bagozzi, R.P. (2000) Self-categorization, affective commitment and group self-esteem as distinct aspects of social identity in the organization. British Journal of Social Psychology 39: 555-577.

Bhattacharya, C.B. and Sen, S. (2003): Consumer-company identification: A framework for understanding consumers' relationships with companies. Journal of Marketing 67(2): 76-88.

Birkigt, K. and Stadler, M.M. (1986) Corporate Identity. Grundlagen, Funktionen und Beispielen, Landsberg an Lech: Verlag Moderne Industrie.

Branscombe, N.R. and Wann, D.L. (1994) Collective self-esteem consequences of outgroup derogation when a valued social identity is on trial. European Journal of Social Psychology 24(6): 641-657.

Brewer, M.B. (1991) The social self - on being the same and different at the same time. Personality and Social Psychology Bulletin 17(5): 475-482. 
Bromley, D.B. (2000) Psychological aspects of corporate identity, image and reputation. Corporate Reputation Review 3(3): 240.

Bromley, D.B. (2001) Relationships between personal and corporate reputation. European Journal of Marketing 35(3/4): 316.

Brown, M.E. (1969) Identification and some conditions of organizational involvement. Administrative Science Quarterly 14(3): 346-355.

Brown, T.J., Dacin, P.A., Pratt, M.G. and Whetten, D.A. (2006) Identity, intended image, construed image, and reputation: An interdisciplinary framework and suggested terminology. Journal of the Academy of Marketing Science 34(2): 99-106.

Chajet, C. and Schatman, T. (1993) Image by Design. Reading, MA: Addison-Wesley.

Christensen, L.T. and Askegaard, S. (2001) Corporate identity and corporate image revisited A semiotic perspective. European Journal of Marketing 35(3/4): 292.

Chun, R. and Davies, G. (2001) E-reputation: The role of mission and vision statements in positioning strategy. Journal of Brand Management 8(4): 315.

Cornelissen, J.P. (2000) Corporate image: an audience centred model. Corporate Communications 5(2): 119-125.

Cornelissen, J.P. and Elving, W.J.L. (2003) Managing corporate identity: An integrative framework of dimensions and determinants. Corporate Communications 8(2): 114.

Cornelissen, J.P., Haslam, S.A. and Balmer, J.M.T. (2007) Social identity, organizational identity and corporate identity: towards an integrated understanding of processes, patternings and products. British Journal of Management 18: S1-S16.

Dacin, P.A. and Brown, T.J. (2002) Corporate identity and corporate associations: A framework for future research. Corporate Reputation Review 5(2/3): 254.

Davies, G., Chun, R., Silva, R.V.D. and Roper, S. (2001) The personification metaphor as a measurement approach for corporate reputation. Corporate Reputation Review 4(2): 113-127. 
de Chernatony, L. and Harris, F. (2000) Developing corporate brands through considering internal and external stakeholders. Corporate Reputation Review 3(3): 268.

Deegan, C., Rankin, M. and Voght, P. (1999) Firms' disclosure reactions to major social incidents: Australian evidence. Proceedings of the 22nd European Accounting Association Congress, Burdeaux.

Dhalla, R. (2007) The construction of organizational identity: Key contributing external and intra-organizational factors. Corporate Reputation Review 10(4): 245-260.

Doosje, B., Ellemers, N. and Spears, R. (1995). Perceived intragroup variability as a function of group status and identification. Journal of Experimental Social Psychology 31(5): 410-436. Dowling, G.R. (1994) Corporate Reputations: Strategies for Developing the Corporate Brand. London: Kogan Page.

Dutton, J.E. and Dukerich, J.M. (1991) Keeping an eye on the mirror: Image and identity in organizational adaptation. Academy of Management Journal 34(3): 517-554.

Dutton, J.E., Dukerich, J.M. and Harquail, C.V. (1994) Organizational images and member identification, Administrative Science Quarterly 39(2): 239-263.

Ellemers, N. and van Rijswijk, W. (1997) Identity needs versus social opportunities: The use of group-level and individual-level identity management strategies as a function of relative group size, status, and ingroup identification. Social Psychology Quarterly 60(1): 52-65.

Ellemers, N., Kortekaas, P. and Ouwerkerk, J.W. (1999) Self-categorisation, commitment to the group and group self-esteem as related but distinct aspects of social identity. European Journal of Social Psychology 29(2-3): 371-389.

Fombrun, C.J. (1996) Reputation: Realizing Value from the Corporate Image. Boston, MA: Harvard Business School Press

Fombrun, C.J. and van Riel, C.B.M. (2004). Fame and Fortune. Upper Saddle River, NJ: Financial Times / Prentice-Hall. 
Gioia, D.A. (1998) From individual to organizational identity. Identity in organizations: Building theory through conversations. 17-31.

Gioia, D.A., Thomas, J.B., Clark, S.M. and Chittipeddi, K. (1994) Symbolism and strategic change in academia: The dynamics of sensemaking and influence. Organization Science: 363383.

Gorb, P. (1992) The psychology of corporate identity. European Management Journal 10(3): 310-314.

Gray, E. and Balmer, J. (1998) Managing image and corporate reputation. Long Range Planning, 31(5): 685-692.

Hall, D.T., Schneider, B. and Nygren, H.T. (1970) Personal factors in organizational identification. Administrative Science Quarterly 15(2): 176-190.

Hatch, M.J. and Schultz, M. (1997) Relations between organizational culture, identity and image. European Journal of Marketing 31(5/6): 356-365.

Hatch, M.J. and Schultz, M. (2002) The dynamics of organizational identity. Human Relations 55(8): 989-1018.

He, H. and Balmer, J.M.T. (2005) The saliency and significance of generic identity: an explanatory study of UK building societies. The International Journal of Bank Marketing 23(4/5): 334-348.

He, H.W. and Balmer, J.M.T. (2007) Identity studies: multiple perspectives and implications for corporate-level marketing. European Journal of Marketing 41(7/8): 765-785.

Hogg, M.A. and Abrams, D. (1998) Social Identifications: A Social Psychology of Intergroup Relations and Group Processes. London: Routledge.

Hogg, M.A. and Terry, D.J. (2000) Social identity and self-categorization processes in organizational contexts. The Academy of Management Review 25(1): 121-140. 
Hogg, M.A., Terry, D.J. and White, K.M. (1995) A tale of two theories: A critical comparison of identity theory with social identity theory. Social Psychology Quarterly 58(4): 255-269.

Holtzhausen, L. and Fourie, L. (2008) Communicating to a diverse workforce. Corporate Communications 13(1): 80.

Hooghiemstra, R. (2000) Corporate communication and impression management - new perspectives why companies engage in corporate social reporting. Journal of Business Ethics 27(1/2): 55-68.

Illia, L. and Balmer, J.M.T. (2012) Corporate communication and corporate marketing. Corporate Communications 17(4): 415-433.

Ingenhoff, D. and Fuhrer, T. (2010) Positioning and differentiation by using brand personality attributes. Corporate Communications 15(1): 83.

Jeyavelu, S. (2009) Organisational identity dissonance in organisational decline and turnaround. Vision: The Journal of Business Perspective 13(2): 33-45.

Karaosmanoglu, E. and Melewar, T.C. (2006) Corporate communications, identity and image: A research agenda. Journal of Brand Management 14(1/2): 196-206.

Kim, J. and Hatcher, C. (2009) Monitoring and regulating corporate identities using the balanced scorecard. Journal of Communication Management 13(2): 116.

Korver, F. and van Ruler, B. (2003) The relationship between corporate identity structures and communication structures. Journal of Communication Management 7(3): 197.

Kottasz, R., Bennett, R., Savani, S. and Ali-Choudhury, R. (2008): The role of corporate art in the management of corporate identity. Corporate Communications 13(3): 235.

Kreiner, G.E. and Ashforth, B.E. (2004) Evidence toward an expanded model of organizational identification. Journal of Organizational Behavior 25(1): 1-27.

Leitch, S. and Motion, J. (1999) Multiplicity in corporate identity strategy. Corporate Communications 4(4): 193-199. 
Leuthesser, L. and Kholi, C. (1997) Corporate identity: The role of mission statements. Business Horizons, 40(3): 59-66.

Lichtenstein, D.R., Drumwright, M.E. and Braig, B.M. (2004) The effect of corporate social responsibility on customer donations to corporate-supported nonprofits. Journal of Marketing 68(4): 16-32.

Mael, F. and Ashforth, B.E. (1992) Alumni and their alma mater: A partial test of the reformulated model of organizational identification. Journal of Organizational Behavior 13(2): 103-122.

Margulies, W.P. (1977) Make the most of your corporate identity. Harvard Business Review 55(4): 66.

Marín, L. and Ruiz, S. (2007) "I need you too!" Corporate identity attractiveness for consumers and the role of social responsibility. Journal of Business Ethics 71(3): 245-260.

Markwick, N. and Fill, C. (1997) Towards a framework for managing corporate identity. European Journal of Marketing 31(5/6): 396.

Melewar, T.C. and Saunders, J. (2000) Global corporate visual identity systems: using an extended marketing mix. European Journal of Marketing 34(5/6): 538.

Melewar, T.C. and Storrie, T. (2001) Corporate identity in the service sector. Public Relations Quarterly 46(2): 20.

Melewar, T.C. and Wooldridge, A.R. (2001) The dynamics of corporate identity: A review of a process model. Journal of Communication Management 5(4): 327.

Melewar, T.C. and Jenkins, E. (2002) Defining the corporate identity construct. Corporate Reputation Review 5(1): 76.

Melewar, T.C. and Karaosmanoglu, E. (2006) Seven dimensions of corporate identity. European Journal of Marketing 40(7/8): 846-869. 
Melewar, T.C., Bassett, K. and Simões, C. (2006) The role of communication and visual identity in modern organisations. Corporate Communications 11(2): 138-147.

Moingeon, B. (1999) From corporate culture to corporate identity. Corporate Reputation Review 2(4): 352.

Moingeon, B. and Ramanantsoa, B. (1997) Understanding corporate identity: The French school of thought. European Journal of Marketing 31(5/6): 383-395.

Oakes, P.J., Haslam, S.A. and Turner, J.C. (1993) Stereotyping and Social Reality. Oxford: John Wiley \& Sons / Blackwell.

Okazaki, S. (2006) Excitement or sophistication? A preliminary exploration of online brand personality. International Marketing Review 23(3): 279.

Olins, W. (1978) The Corporate Personality: An Inquiry into the Nature of Corporate Identity. London: Design Council.

Olins, W. (1989) Corporate Identity: Making Business Strategy Visible Through Design. London: Thames and Hudson.

Otubanjo, B.O. and Melewar, T.C. (2007) Understanding the meaning of corporate identity: a conceptual and semiological approach. Corporate Communications 12(4): 414-432.

Powell, S., Elving, W.J.L., Dodd, C. and Sloan, J. (2009) Explicating ethical corporate identity in the financial sector. Corporate Communications 14(4): 440.

Price, K.N., Gioia, D.A. and Corley, K.G. (2008) Reconciling scattered images. Journal of Management Inquiry 17(3): 173-185.

Ravasi, D. and van Rekom, J. (2003) Academic research key issues in organizational identity and identification theory. Corporate Reputation Review 6(2): 118-132.

Reitter, R. and Ramanantsoa, B. (1985) Povoir et politique. Au dèla de la cultuire d’enterprise. Paris: McGraw-Hill. 
Rolland, D. and Bazzoni, J.O. (2009) Greening corporate identity: CSR online corporate identity reporting. Corporate Communications 14(3): 249.

Schmidt, K. (1996) The Quest for Identity: Corporate Identity, Strategies, Methods and Examples. London: Thomson Learning.

Schmitt, B.H., Simonson, A. and Marcus, J. (1995) Managing corporate image and identity. Long Range Planning 28(5): 82-92.

Schultz, M., Hatch, M.J. and Larsen, M.H. (2000) The Expressive Organization: Linking Identity, Reputation, and the Corporate Brand. London: Oxford University Press.

Scott, S.G. and Lane, V.R. (2000) A stakeholder approach to organizational identity. The Academy of Management Review 25(1): 43-62.

Selame, E. and Selame, J. (1975) Developing a Corporate Identity: How to Stand Out in the Crowd. New York: John Wiley \& Sons.

Souiden, N., Kassim, N.M. and Hong, H. (2006) The effect of corporate branding dimensions on consumers' product evaluation: A cross-cultural analysis. European Journal of Marketing 40(7/8): 825-845.

Stuart, H. (1999) Towards a definitive model of the corporate identity management process. Corporate Communications 4(4): 200.

Tajfel, H. (1978) Differentiation Between Social Groups. London: Academic Press.

Tajfel, H. (1984) The Social Dimension: European Developments in Social Psychology. Cambridge: Cambridge University Press.

Tajfel, H. and Turner, J.C. (1979) An integrative theory of intergroup conflict. In: eds. W. Austin and S. Worchel (eds.) The Social Psychology of Intergroup Relations. Monterrey: Brooks-Cole, pp. 33-47.

Tajfel, H. and Turner, J.C. (1986) The social identity theory on intergroup behavior. In: S. Worchel and W.G. Austin (eds.) Psychology of Intergroup Relations. Chicago: Nelson-Hall. 
Topalian, A. (1984) Corporate identity: Beyond the visual overstatements. International Journal of Advertising 3(1): 55-62.

Tsai, S. (2008) Corporate marketing management and corporate-identity building. Marketing Intelligence and Planning 26(6): 621.

Turner, J.C. (1982) Towards a cognitive redefinition of the social group. In: H. Tajfel (ed.) Social identity and Intergroup Relations. Cambridge: Cambridge University Press.

Turner, J.C. (1991) Social Influence. Buckingham: Open University Press.

Turner, J.C., Hogg, M.A., Oakes, P.J., Reicher, S.D. and Wetherell, M.S. (1987)

Rediscovering the Social Group: A Self-categorization Theory. Oxford: Blackwell.

van Rekom, J. (1997) Deriving an operational measure of corporate identity. European Journal of Marketing, 31(5/6): 410-422.

van Rekom, J., Corley, K. and Ravasi, D. (2008) Extending and advancing theories of organizational identity. Corporate Reputation Review 11(3): 183-188.

van Riel, C.B.M. (1995) Principles of Corporate Communication. Hemel Hempstead: Prentice-Hall.

van Riel, C.B.M. and Balmer, J.M.T. (1997) Corporate identity: the concept, its measurement and management. European Journal of Marketing 31(5/6): 340-355.

van Riel, C.B.M. and Fombrun, C.J. (2007) Essentials of Corporate Communication. New York: Routledge.

Walker, K. (2010) A systematic review of the corporate reputation literature: Definition, measurement, and theory. Corporate Reputation Review 12(4): 357-387.

Wei, Y. (2002) Corporate image as collective ethos: A poststructuralist approach. Corporate Communications 7(4): 269-276.

Whetten, D.A. (2006) Albert and Whetten revisited: Strengthening the concept of organizational identity. Journal of Management Inquiry 15(3): 219-234. 
Zarebska, A. (2010) Practical problems of managing corporate identity of capital structures

in Poland. The International Business \& Economics Research Journal 9(1): 9.

\section{Appendix}

A review of academic proposals for the definition of corporate identity is included in Table 3.

Table 3. Definitions of identity

\begin{tabular}{|c|c|}
\hline References & Definition \\
\hline \multicolumn{2}{|r|}{$\begin{array}{c}\text { Identity as organizational personality } \\
\text { (it answers the question 'who are we as an organization?') } \\
\end{array}$} \\
\hline $\begin{array}{ll}\text { Reitter } & \text { and } \\
\text { Ramanantsoa } \\
(1985)\end{array}$ & $\begin{array}{l}\text { Set of interdependent characteristics of the organization that give it } \\
\text { specificity, stability and coherence and thus make it identifiable }\end{array}$ \\
\hline Abratt (1989) & $\begin{array}{l}\text { A set of visual cues -physical and behavioral- that make the firm } \\
\text { different and distinguish it from other. These cues are used to symbolize } \\
\text { and represent the firm }\end{array}$ \\
\hline van Rekom (1997) & $\begin{array}{l}\text { A set of meanings by which the company allows itself to be known and } \\
\text { through which it allows people to describe remember and relate to it }\end{array}$ \\
\hline $\begin{array}{l}\text { Gray and Balmer } \\
\text { (1998) }\end{array}$ & The distinct characteristics of the firm \\
\hline Balmer (1995) & What the organization 'is’, i.e. its innate character \\
\hline $\begin{array}{l}\text { van Riel and } \\
\text { Balmer (1997) }\end{array}$ & $\begin{array}{l}\text { Core, enduring, and distinctive features of a firm that produce shared } \\
\text { interpretations among managers about how they should accommodate to } \\
\text { external circumstances }\end{array}$ \\
\hline Moingeon (1999) & $\begin{array}{l}\text { A set of interdependent characteristics of the organization that give it } \\
\text { specificity, stability, and coherence, and thus make it identifiable }\end{array}$ \\
\hline $\begin{array}{l}\text { de Chernatony and } \\
\text { Harris 2000) }\end{array}$ & $\begin{array}{l}\text { An organization's ethos, aims and values that create a sense of } \\
\text { individuality, differentiating the brand }\end{array}$ \\
\hline Bromley (2001) & $\begin{array}{l}\text { The set of attributes that distinguishes one organization from another, } \\
\text { especially organizations of the same sort }\end{array}$ \\
\hline $\begin{array}{l}\text { Christensen and } \\
\text { Askegaard (2001) }\end{array}$ & $\begin{array}{l}\text { The total sum of signs that stands for an organization to its various } \\
\text { audiences }\end{array}$ \\
\hline $\begin{array}{l}\text { Argenti and } \\
\text { Druckenmiller } \\
(2004)\end{array}$ & Company’s defining attributes, such as its people, products and services \\
\hline Whetten (2006) & $\begin{array}{l}\text { The central and enduring attributes of an organization that distinguish it } \\
\text { from other organizations. I refer to these as organizational identity } \\
\text { claims, or referents, signifying an organization's self-determined (and } \\
\text { "self"-defining) unique social space and reflected in its unique pattern } \\
\text { of binding commitments }\end{array}$ \\
\hline
\end{tabular}




\begin{tabular}{ll}
\hline \hline References & Definition \\
\hline \hline $\begin{array}{l}\text { Balmer and } \\
\text { Greyser (2006) }\end{array}$ & What we undoubtedly are \\
\hline Jeyavelu (2009) & $\begin{array}{l}\text { The sum total of answers to the question 'who are we?'; or the shared } \\
\text { beliefs, collective mental framework, cognitive map or collective self- } \\
\text { reflective narratives of the central, enduring and distinctive (CED) } \\
\text { characteristics of the organization. }\end{array}$ \\
\hline \hline
\end{tabular}

\section{Identity as organizational image}

(it answers the question 'who do we want others to think we are as an organization?')

\begin{tabular}{ll}
\hline $\begin{array}{l}\text { Albert and } \\
\text { Whetten (1985) }\end{array}$ & $\begin{array}{l}\text { How organization's members express cultural values and develop a } \\
\text { collective self-definition of the organization based on its central, } \\
\text { enduring and distinctive attributes }\end{array}$ \\
\hline Fombrun (1996) & $\begin{array}{l}\text { The set of values and principles employees and managers associate with } \\
\text { the company }\end{array}$ \\
\hline $\begin{array}{l}\text { Hatch and Schultz } \\
\text { (1997) }\end{array}$ & What members perceive, feel and think about their organizations \\
\hline Bromley (2000) & $\begin{array}{l}\text { The way key members conceptualize their organization } \\
\text { Fombrun and van } \\
\text { Riel (2004) }\end{array}$ \\
$\begin{array}{l}\text { company, (b) features that make the company distinctive from other } \\
\text { companies (in the eyes of the employees) and (c) features that are } \\
\text { enduring or continuing, linking the present and the past to the future }\end{array}$ \\
\hline Dhalla (2007) & $\begin{array}{l}\text { Organizational members' view of the organization to which they belong } \\
\text { and their collective belief and understanding of what the organization is }\end{array}$ \\
\hline Price et al. (2008) & $\begin{array}{l}\text { Who members believe themselves to be as an organization. Can usefully } \\
\text { be viewed as a special case of organizational image }\end{array}$ \\
\hline \hline
\end{tabular}

\section{Identity as visual image}

(it refers to symbolism)

\begin{tabular}{|c|c|}
\hline $\begin{array}{l}\text { Selame } \\
\text { Selame (1975) }\end{array}$ & $\begin{array}{l}\text { The firm's visual statement to the World of who and what the company } \\
\text { is (of how the company views itself) }\end{array}$ \\
\hline Carter (1982) & $\begin{array}{l}\text { The logo or brand image of a company and all other visual } \\
\text { manifestations of the identity of a company }\end{array}$ \\
\hline $\begin{array}{l}\text { Schmitt et al. } \\
\text { (1995) }\end{array}$ & $\begin{array}{l}\text { The degree to which the firm has achieved a distinct and coherent image } \\
\text { in its aesthetic output (packaging, logos, trade names, business cards, } \\
\text { company uniforms, buildings and advertisements) }\end{array}$ \\
\hline $\begin{array}{l}\text { Alessandri and } \\
\text { Alessandri (2004) }\end{array}$ & $\begin{array}{l}\text { Firm's strategically planned and purposeful presentation of itself in } \\
\text { order to gain a positive corporate image in the minds of the public. In } \\
\text { practice, a firm's corporate identity refers to all of the observable and } \\
\text { measurable elements manifest in its visual presentation, including its } \\
\text { name, logo, tagline, color palette, interior design and architecture }\end{array}$ \\
\hline \multicolumn{2}{|r|}{$\begin{array}{l}\text { Identity as a collection of corporate communication means } \\
\text { (it refers to symbolism + behavior + verbal communication) }\end{array}$} \\
\hline Margulies (1977) & $\begin{array}{l}\text { The sum of all the ways a company chooses to identify itself to all its } \\
\text { publics (the community, customers, employees, the press, present and } \\
\text { potential stockholders, security analysts, and investment bankers) }\end{array}$ \\
\hline $\begin{array}{l}\text { Birkigt and Stadler } \\
\text { (1986) }\end{array}$ & $\begin{array}{l}\text { Strategically planned and operationally applied internal and external } \\
\text { self-presentation and behavior of a company }\end{array}$ \\
\hline van Riel (1995) & $\begin{array}{l}\text { Self-presentation of the company which is projected through its } \\
\text { behavior, communications and symbolism }\end{array}$ \\
\hline
\end{tabular}




\begin{tabular}{|c|c|}
\hline References & Definition \\
\hline $\begin{array}{l}\text { Olins (1995, in } \\
\text { Melewar et al., } \\
\text { 2006) }\end{array}$ & $\begin{array}{l}\text { The explicit management of all the ways in which the organization } \\
\text { presents itself through experience and perceptions to all its audience }\end{array}$ \\
\hline $\begin{array}{l}\text { van Riel and } \\
\text { Balmer (1997) }\end{array}$ & $\begin{array}{l}\text { The self-presentation of an organization, rooted in the behavior of } \\
\text { individual organizational members, expressing the organization's } \\
\text { "sameness over time" or continuity, "distinctiveness", and "centrality" }\end{array}$ \\
\hline $\begin{array}{l}\text { Korver and van } \\
\text { Ruler (2003) }\end{array}$ & The way in which a company makes itself known to the world \\
\hline $\begin{array}{l}\text { Karaosmanoglu } \\
\text { and } \quad \text { Melewar } \\
(2006)\end{array}$ & $\begin{array}{l}\text { The strategically planned expressions of corporate personality via the } \\
\text { cues given by its symbols, behavior and communication }\end{array}$ \\
\hline & $\begin{array}{l}\text { Identity as an integrative concept } \\
\text { (it refers to a multidisciplinary approach) }\end{array}$ \\
\hline Balmer (2001a) & $\begin{array}{l}\text { An umbrella label used to cover corporate personality, organizational } \\
\text { identification and visual identity }\end{array}$ \\
\hline Topalian (1984) & $\begin{array}{l}\text { The articulation of what the organization is, what it does and how it } \\
\text { does it }\end{array}$ \\
\hline $\begin{array}{l}\text { Markwick and Fill } \\
\text { (1997) }\end{array}$ & $\begin{array}{l}\text { The articulation of what the organization is, what it does and how it } \\
\text { does it, the organization's presentation of itself to its various } \\
\text { stakeholders and the means by which it distinguishes itself from all } \\
\text { other organizations }\end{array}$ \\
\hline $\begin{array}{l}\text { Melewar and } \\
\text { Wooldridge (2001) }\end{array}$ & $\begin{array}{l}\text { Strategic manifestation of corporate-level vision and mission, } \\
\text { underpinned by the strategies which a corporation employs in its } \\
\text { operations or production; the marketing strategy and mix which } \\
\text { determines the product/service brand; and the human resource strategy } \\
\text { which affects the manner in which the products/services are delivered }\end{array}$ \\
\hline $\begin{array}{l}\text { Dacin and Brown } \\
(2002)\end{array}$ & $\begin{array}{l}\text { Intended characteristics of an organization that decision-makers an } \\
\text { marketers within the group choose to promote to their internal and } \\
\text { external constituents }\end{array}$ \\
\hline $\begin{array}{l}\text { Cornelissen and } \\
\text { Elving (2003) }\end{array}$ & $\begin{array}{l}\text { Strategic development of a distinct and coherent image of an } \\
\text { organization that is consistently communicated to stakeholders through } \\
\text { symbolism, planned communications and behavior }\end{array}$ \\
\hline $\begin{array}{l}\text { Melewar and } \\
\text { Karaosmanoglu } \\
\text { (2006) }\end{array}$ & $\begin{array}{l}\text { Presentation of an organization to every stakeholder. It is what makes } \\
\text { an organization unique and it incorporates the organization's } \\
\text { communication, design, culture, behavior, structure, industry identity } \\
\text { and strategy. It is thus intrinsically related to corporate personality and } \\
\text { image }\end{array}$ \\
\hline $\begin{array}{l}\text { Powell et al. } \\
(2009)\end{array}$ & $\begin{array}{l}\text { Projected corporate personality where corporate personality is at the } \\
\text { heart of the organization and embodies the corporate mission, corporate } \\
\text { philosophy and core values of the organization }\end{array}$ \\
\hline Zarebska (2010) & $\begin{array}{l}\text { A system embracing all visual, verbal and behavioral announcements } \\
\text { that the organization sends to its internal and/or external environment, } \\
\text { which expresses the values and beliefs that the company follows in its } \\
\text { every-day operations that aim at making company distinct from others } \\
\text { as well as at building competitive advantage by taking specific place in } \\
\text { consumers' minds }\end{array}$ \\
\hline
\end{tabular}

Source: Compiled by author 
Note: for the compilation of references in this table the authors have only considered complete definitions provided by scholars. For the purpose of gaining accuracy in the interpretation of this table, the authors have avoided elaborating definitions which would mean interpreting ideas by earlier authors who have not provided a definition per se. Thus, this is only a selection and not a detailed list of papers which have analyzed either organizational or corporate identities. 